\title{
Wave directional measurement in Patos Lagoon, RS, Brazil
}

\author{
Medição direcional das ondas na Lagoa dos Patos, RS, Brasil
}

\author{
Natália Lemke ${ }^{1}$, Lauro Julio Calliari ${ }^{1}$, José Antônio Scotti Fontoura ${ }^{1}$ and Déborah Fonseca Aguiar ${ }^{1}$ \\ ${ }^{1}$ Universidade Federal do Rio Grande, Rio Grande, RS, Brasil \\ E-mails: natalialemke@gmail.com (NL), lcalliari@log.furg.br (LJC), scottifontoura@gmail.com (JASF), deborahaguiar09@gmail.com (DFA)
}

Received: May 05, 2016 - Revised: August 31, 2016 - Accepted: September 05, 2016

\begin{abstract}
The wave climate characterization in coastal environments is essentially important to oceanography and coastal engineering professionals regarding coastal protection works. Thus, this study aims to determine the most frequent wave parameters (significant wave height, peak period and peak direction) in Patos Lagoon during the period of operation of a directional waverider buoy (from 01/27/2015 to 06/30/2015). The equipment was moored at approximately $14 \mathrm{~km}$ from the São Lourenço do Sul coast at the geographic coordinates of $31^{\circ} 29^{\prime} 06^{\prime \prime} \mathrm{S}$ and $51^{\circ} 55^{\prime} 07^{\prime \prime} \mathrm{W}$, with local depth of six meters, registering significant wave height, peak period and peak direction time series. During the analyzed period, the greatest wave frequencies corresponded to short periods (between 2 and 3.5 seconds) and small values of significant wave heights (up to 0.6 meters), with east peak wave directions. The largest wave occurrences corresponded to east peak wave directions (33.3\%); peak wave periods between 2.5 and 3 seconds (25.6\%) and between 3 and 3.5 seconds (22.1\%); and to significant wave heights of up to 0.3 meters $(41.2 \%)$ and from 0.3 to 0.6 meters $(38 \%)$. This research yielded unprecedented findings to Patos Lagoon by describing in detail the most occurring wave parameters during the analyzed period, establishing a consistent basis for several other studies that might still be conducted by the scientific community.
\end{abstract}

Keywords: Waves in Patos Lagoon; Waverider buoy; Wave climate in Patos Lagoon.

\section{RESUMO}

A caraterização do clima de ondas em ambientes costeiros representa fundamental importância para profissionais da oceanografia e da engenharia oceânica no que diz respeito a obras de proteção litorânea. Desta forma, este estudo tem por objetivo determinar os parâmetros de ondas (alturas significativas, períodos de pico e direções de pico) mais frequentes na Lagoa dos Patos durante o período de operação de um ondógrafo direcional (27/01/2015 a 30/06/2015). Fundeado a aproximadamente 14 km da costa de São Lourenço do Sul, no ponto de coordenadas $31^{\circ} 29^{\prime} 06^{\prime}$ 'S e 51 55'07' W, com profundidade local de seis metros, o equipamento registrou séries temporais de alturas significativas, períodos de pico e direções de pico das ondas. Durante o período analisado, as maiores frequências de ondas corresponderam a curtos períodos (entre 2 e 3,5 segundos) e a pequenos valores de alturas significativas (até 0,6 metros), com direções de pico provenientes de leste. As maiores ocorrências de ondas corresponderam às direções de pico provenientes de leste $(33,3 \%)$, aos períodos de pico entre 2,5 e 3 segundos $(25,6 \%)$ e entre 3 e 3,5 segundos $(22,1 \%)$, e às alturas significativas de até 0,3 metros $(41,2 \%)$ e de 0,3 a 0,6 metros $(38 \%)$. Esta pesquisa produziu resultados inéditos para a Lagoa dos Patos, descrevendo detalhadamente os parâmetros de ondas mais ocorrentes durante o período analisado, formando uma base consistente a diversos outros estudos que ainda poderão ser realizados pela comunidade científica.

Palavras-chave: Ondas na Lagoa dos Patos; Ondógrafo; Clima ondulatório da Lagoa dos Patos. 


\section{INTRODUCTION}

Knowing the wave regime in coastal environments, either oceanic or lagoon, is of fundamental importance to coastal engineering and oceanography professionals. According to Silva and Alfredini (2001), the determination of the wave parameters in the surf zone is essential to design coastal engineering works since they promote the sedimentary transport along the coast, as well as producing forces that act against maritime or lacustrine structures. The determination of the project wave is essential for the stabilization of coastal structures. The effects of physical processes related to waves are extremely important to costal works' projects, as breakwaters and groins, but also to naval engineering. According to Strauch et al. (2009), the wave climate determination in coastal environments is important to engineering projects, navigation safety and coastal management.

According to Machado (2013), the wave climate characterization of a region is determined through the statistical standard of the descriptive parameters: height, period, direction of propagation and energy. The climate, localization of atmospheric systems, prevailing wind regime and its spatial range are factors that directly contribute to the wave climate characterization. As stated by Assis et al. (2013), the wind transfers energy from the atmosphere to the sea and generates sea agitation, where gravity acts as a restoring force. According to Neves (2014), the heights of gravity waves are determined through direct measurements of the free surface, or calculated from the water column pressure, acceleration of a buoy, punctual velocity of a water column elevation or vertical velocity profile.

According to Moura, Fortes and Neves (2012), there are various pieces of equipment that can measure the wave incidence angle, such as buoys with accelerometers (waverider type), electromagnetic current meters associated with pressure sensors, and acoustical instruments (as PUV or ADCP). Several authors used waverider buoys to make wave measurements. Strauch et al. (2001) monitored the wave climate along the Rio Grande (RS, Brazil) coast using a directional waverider buoy moored at approximately $15 \mathrm{~km}$ from the coastline. Strauch et al. (2009) compared the sea wave data between the south and north Rio Grande do Sul coast acquired by a directional waverider buoy moored near the Patos Lagoon mouth (October,1996), and then in the Tramandai beach (November, 2006), both at the 17-m isobath. Pimenta et al. (2013) worked with a wave buoy moored along Santa Catarina Island from December 2001 to November 2003. Assis et al. (2013) evaluated the energy potential of sea waves in the Rio Grande do Sul coast using wave data collected offshore from the Rio Grande harbor from 1996 to 1999. Moeini and Etemad-Shahidi (2009) worked with wave parameters measured by three waverider buoys in Lake Erie (in the Canada-United States boarder) to validate a wave-generating model in the region. Seibt et al. (2013) compared wave height data measured by a pressure sensor in Lake Überlingen (Germany) with modeled data. Smith (2012) validated a wave-generating model in Lake George (Australia) using wave parameters measured by waverider buoys. Westhuysen (2010) analyzed the performance of a wave-generating model in lakes Sloten (Netherlands), IJseel (Netherlands) and George (Australia) using wave data acquired by wave buoys.
Research based on wave data measurements in lagoons and coastal lagoons is still very limited. Differently from lagoons (closed water bodies), according to Miranda et al. (2002), the coastal lagoons present dynamic characteristics related to the quantity of water exchanged with the ocean. The coastal lagoons can be driven by fresh water flux, wind stress and tides. Therefore, according to the geomorphological characterization of this study area, Patos Lagoon can be classified as a coastal lagoon.

According to Fontoura et al. (2015), Patos Lagoon is the main water body of the Mercosul Waterway, and until 2015, there were no records of a detailed study of its wave regime. Research on the wave climate characterization in the lagoon body is still limited. Nicolodi, Toldo Junior and Farina (2013) validated a wave-generating model in Lake Guaíba through the correlation with data obtained through the deployment of a FSI3D waverider buoy produced by Falmouth Scientific, which was moored near Jangadeiros club in the southern area of Porto Alegre, from June 16 to August 2, 2005, at approximately 3 meters deep. Fischer and Calliari (2011) made wave height measurements using a graduated ruler located at 0.50 meters deep on the "Saco do Laranjal" beaches (northwest coast of the Patos Lagoon estuary). The measurements were made in March 2004 in order to validate a wave-generating model. Toldo Junior et al. (2006) made the first wind measurements and wave predictions along the Patos Lagoon west and east margins based on hourly wind intensity and direction data throughout 1988. In Lemke et al. (2015), the calibration of the SWAN model applied to Patos Lagoon was made through the correlation with the wave parameters measured by a directional waverider buoy during March 2015. Lemke (2015) simulated wave generation and propagation throughout the lagoon body by using SWAN for the year of 2008, and analyzed the results at specific spots near São Lourenço do Sul.

There are several beaches and river mouths in Patos Lagoon that are under sediment erosion and/or deposition process and, therefore, requiring some sort of coastal work that assists in its protection; but without knowing the wave regime in the region, any decision making becomes difficult. In this way, this work aims to analyze the parameters of significant wave height (Hs), peak wave period (Tp) and peak wave direction (Dir) measured by a directional waverider buoy in Patos Lagoon during the period from January 27 to June 30, 2015.

\section{MATERIAL AND METHODS}

\section{Study area}

Patos Lagoon (Figure 1) is a large coastal lagoon that has an average length of $250 \mathrm{~km}$ and an average width of $40 \mathrm{~km}$, covering an area of approximately $10,360 \mathrm{~km}^{2}$. It has a general NE-SW orientation, parallel to the Rio Grande do Sul coastline, and is mostly protected from the Atlantic Ocean waters by a sandy barrier system. This system extends from the north of the coastal lagoon to its south end, where there is a channel of communication with the sea through the jetties in the Rio Grande's channel (TOLDO JUNIOR, 1991). In accordance with its average depth of 5 meters, Patos Lagoon is classified as a shallow coastal lagoon (MÖLLER JUNIOR et al., 1996). It presents a microtidal regime, with an 


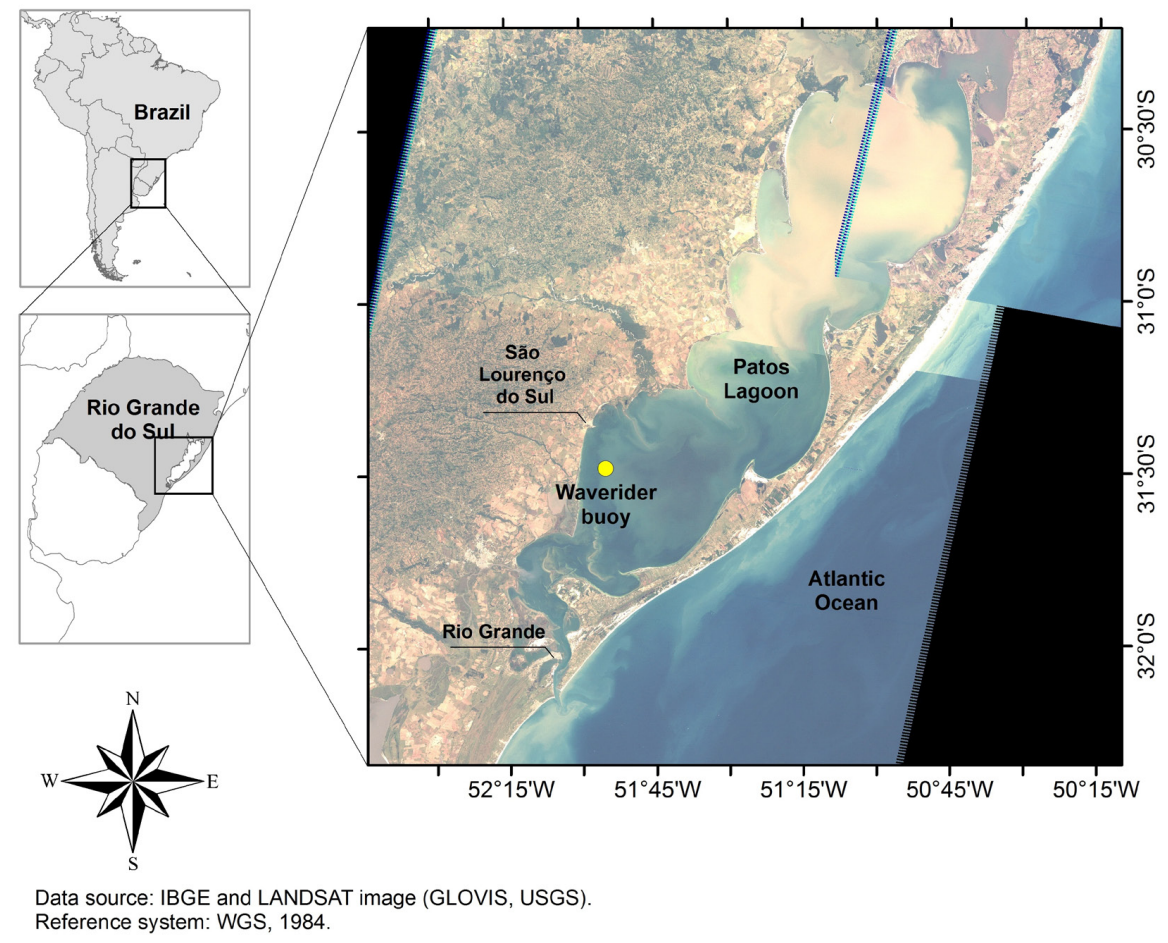

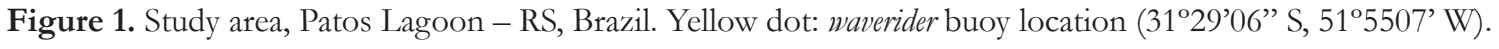

astronomical tide amplitude of 0.45 meters (MARTINS et al., 1989). Its lateral margins are formed by recurved sand spits associated with the alongshore transport resultant from obliquely incident waves (TOLDO JUNIOR, 1994). Due to being a microtidal region, the hydrodynamic regime between Patos Lagoon and the coastal ocean is driven by the wind.

\section{Acquisition of wave parameters by the directional waverider buoy}

The directional Waverider Datawell Mark III wave buoy (Figure 2) used in this study belongs to FURG via the "Rede Ondas (Rede de Monitoramento de Ondas em Águas Rasas)" project of the Interministerial Commission for the Sea Resources. The equipment was manufactured by the Dutch company Datawell, weighting approximately $300 \mathrm{~kg}$ and consisting of a spherical hull of 0.9 meters in diameter, which houses several sensors. In its external portion, it has a rubber cord for protection and a stainless-steel triangle to avoid spinning. The equipment records wave height, period, direction, temperature and geographic position. The wave height and wave direction measurements are made through accelerometers, which measure the time series of its spatial movement (horizontal and vertical displacements). The waverider buoy has a $3.84-\mathrm{Hz}$ sampling rate and measures waves with periods varying from 1.6 to 30 seconds. The resolution of the obtained measurements is about $1 \mathrm{~cm}$ for wave height, $1.5^{\circ}$ for wave direction and $0.05^{\circ} \mathrm{C}$ for water temperature. The precision of the GPS that transmits its geographic position is up to 10 meters (DATAWELL BV, 2010).

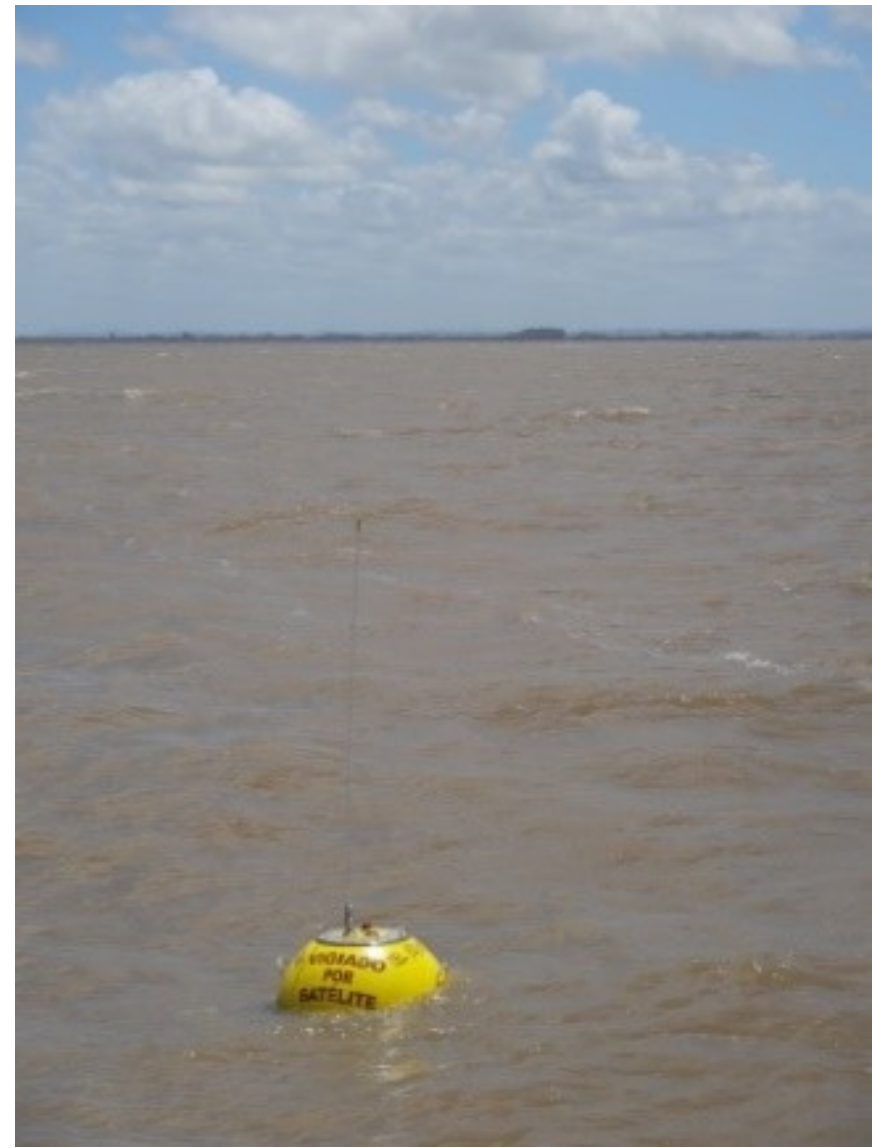

Figure 2. Directional waverider buoy in Patos Lagoon. 
The frequency spectrum is calculated every 30 minutes by an internal microprocessor using the amount of raw data obtained in this time interval and it is immediately transmitted to the land base. The raw and spectral data transmission is done every hour through a radio antenna positioned at the top of the waverider buoy. The radio operation frequency is between 25.5 and $35.5 \mathrm{MHz}$. The equipment records one vertical displacement (elevation) and two horizontal displacements (north and west). In this way, the variance, kurtosis and asymmetry are computed. The collected data visualization can be done in real time in $2 \mathrm{D}$ and $3 \mathrm{D}$ formats through theW@ves21 (W21) software, developed by Datawell. This software analyses, processes and presents the data recorded by the equipment. For the real-time data display, the W@ves21 program needs to be connected to the rfBouy module. Thus, the waverider buoy can be monitored by any computer. The significant wave height is calculated through the W@ves21 (W21) software by performing the zero-crossing analysis, which uses the average of $1 / 3$ of the highest wave heights (DATAWELL BV, 2006).

On January 22, 2015, the first directional waverider buoy mooring in Patos Lagoon was deployed at approximately $14 \mathrm{~km}$ offshore from the São Lourenço do Sul coast, at $31^{\circ} 29^{\prime} 06^{\prime \prime} \mathrm{S}$ and $51^{\circ} 5507^{\prime} \mathrm{W}$ (Figure 1) and $6 \mathrm{~m}$ deep. The equipment was in operation until July 1, 2015, recording wave heights, periods and directions, water temperature, and the geographic position. Through a radio antenna positioned at the top of the waverider buoy, the raw and spectral data were transmitted to a receiving station located at FURG - Campus São Lourenço do Sul, and then via Internet to FURG - Rio Grande (Figure 3). Wave parameters (significant wave height, peak period and peak direction) were released in real time at the website redeondas.herokuapp.com.

\section{Wave parameter analysis}

After the data processing using the W@ves21 software, the occurrence frequencies of the significant wave heights (Hs) and peak wave periods ( $\mathrm{Tp}$ ) were calculated according to the peak wave directions (Dir).

\section{RESULTS AND DISCUSSION}

\section{Results from the wave parameter analysis}

From the wave data recorded by the waverider buoy and transmitted through radio to the antenna installed at FURG - Campus São Lourenço do Sul, it was possible to analyze the occurrence frequencies of the significant wave height and peak wave period parameters according to the peak wave directions. Thus, the results presented in this section correspond to the files generated every half hour by the W@ves21 (W21) software, where the significant wave heights were calculated from the average of $1 / 3$ of the highest wave heights through the zero-crossing analysis. During the first days of the equipment's operation in Patos Lagoon, there were some difficulties related to the signal reception, leading to data loss. Therefore, the process of recording

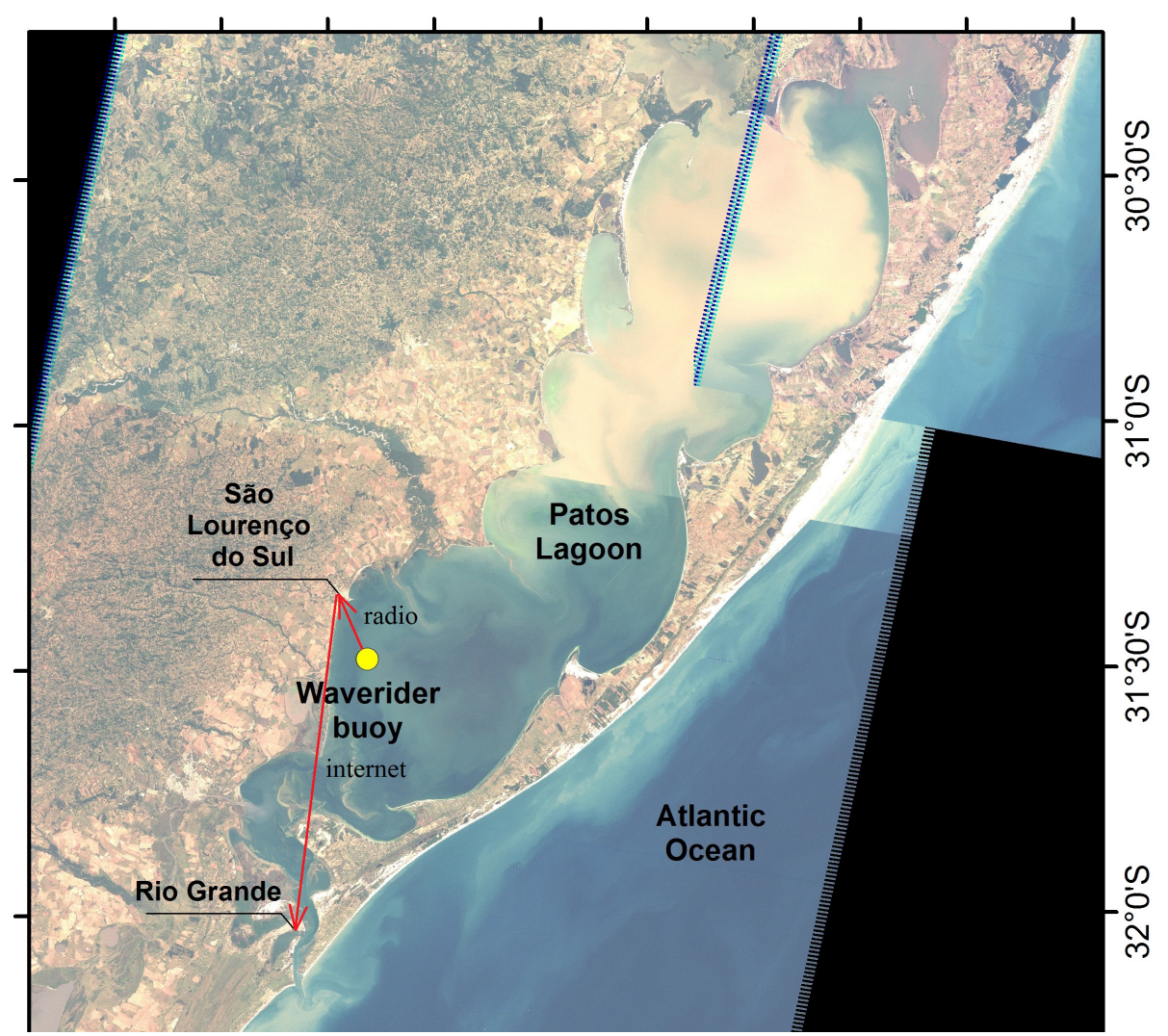

Figure 3. Data transmission scheme. 
wave data effectively initiated on January 27, 2015. It is important to highlight that, from that day on, the wave data reception has become more efficient; however, there were still some records that were lost due to technical faults that occurred in the receiving computer located at FURG - Campus São Lourenço do Sul.

Figures 4 and 5 show, respectively, the wave rose diagrams and the occurrence frequency histograms for the significant wave

(a)

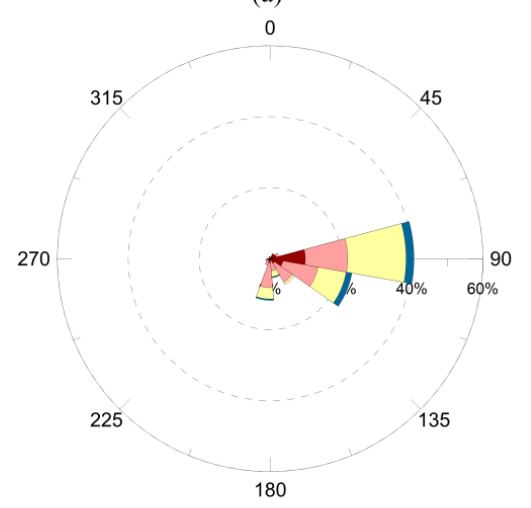

(c)

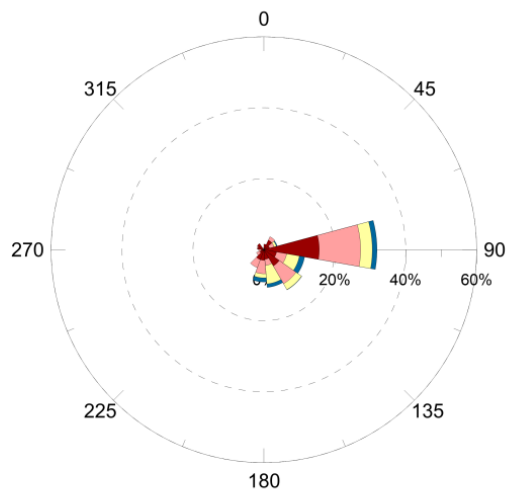

(e)

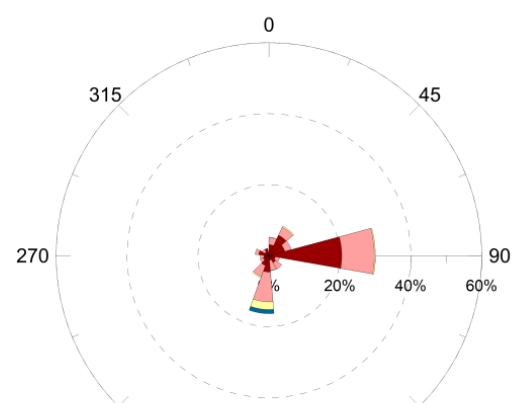

225 135 height according to the wave peak direction. Figures 6 and 7 illustrate the wave rose diagrams and the occurrence frequency histograms, respectively, for the wave peak period according to the wave peak direction.

Both Figures 4 and 7 are presented according to the data analysis periods: from $01 / 27 / 2015$ to $02 / 28 / 2015$, from $03 / 01 / 2015$ to $03 / 31 / 2015$, from $04 / 01 / 2015$ to $04 / 30 / 2015$,

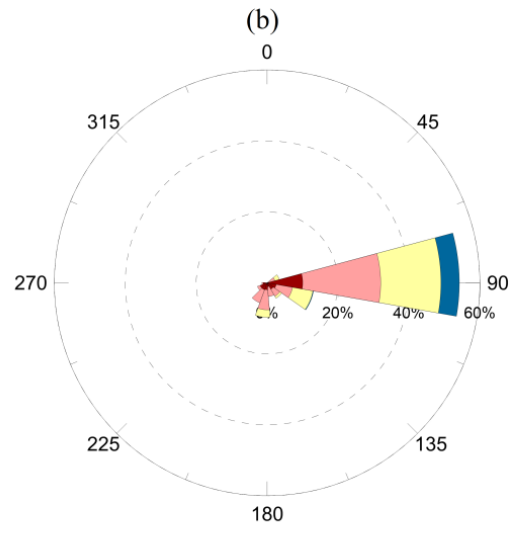

(d)

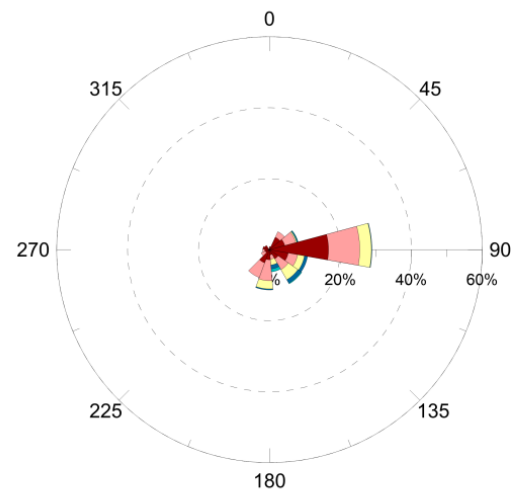

180

(f)

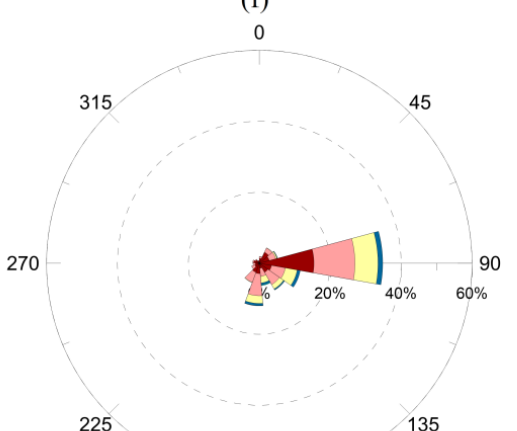
225

180

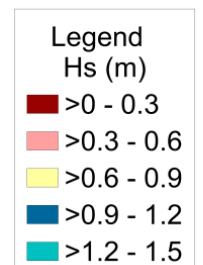

Figure 4. Hs wave rose diagrams according to peak wave directions. (a) from 01/27/2015 to 02/28/2015; (b) from 03/01/2015 to $03 / 31 / 2015$; (c) from $04 / 01 / 2015$ to $04 / 30 / 2015$; (d) from $05 / 01 / 2015$ to $05 / 31 / 2015$; (e) from $06 / 01 / 2015$ to $06 / 30 / 2015$ and (f) from $01 / 27 / 2015$ to $06 / 30 / 2015$. 

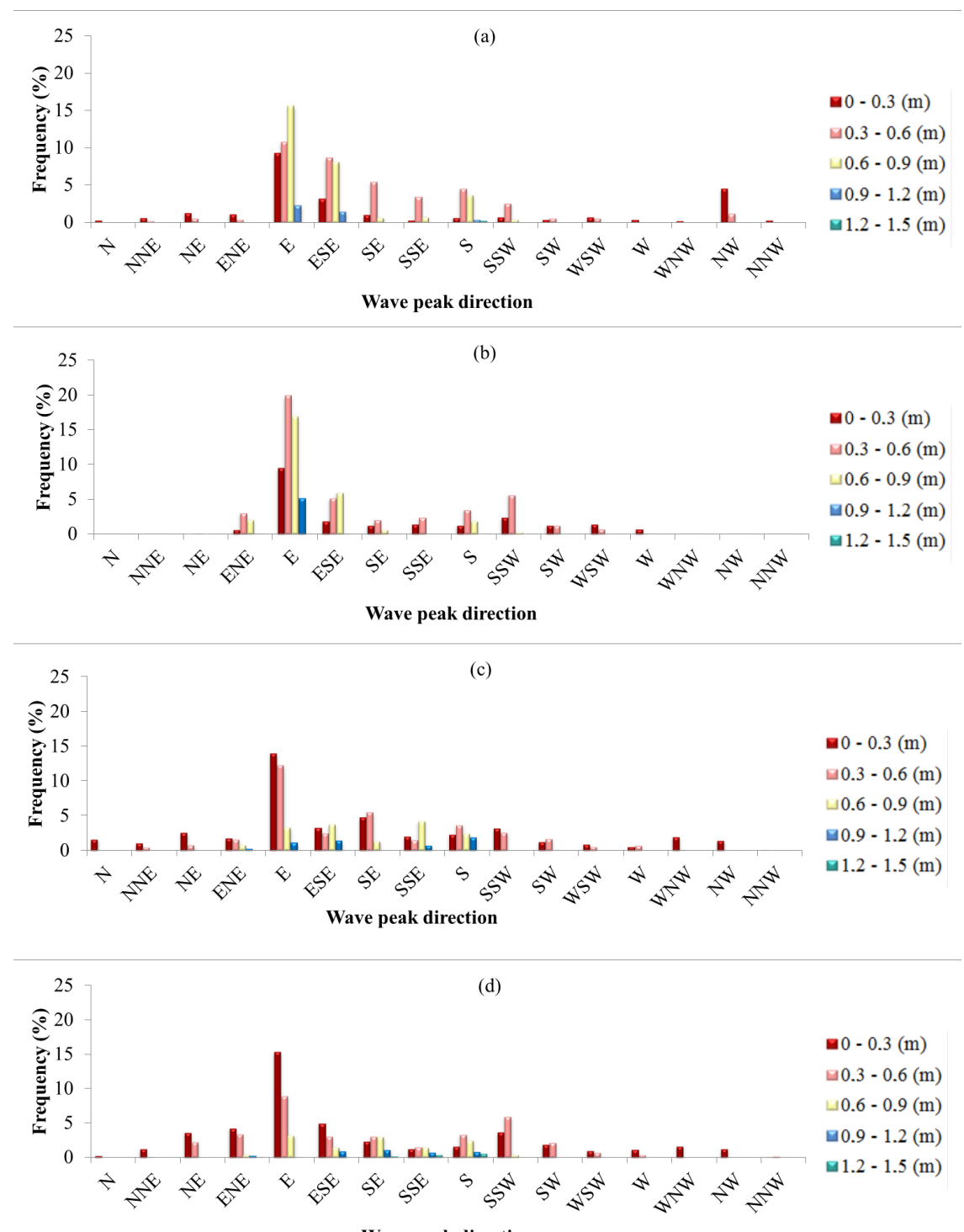

Wave peak direction

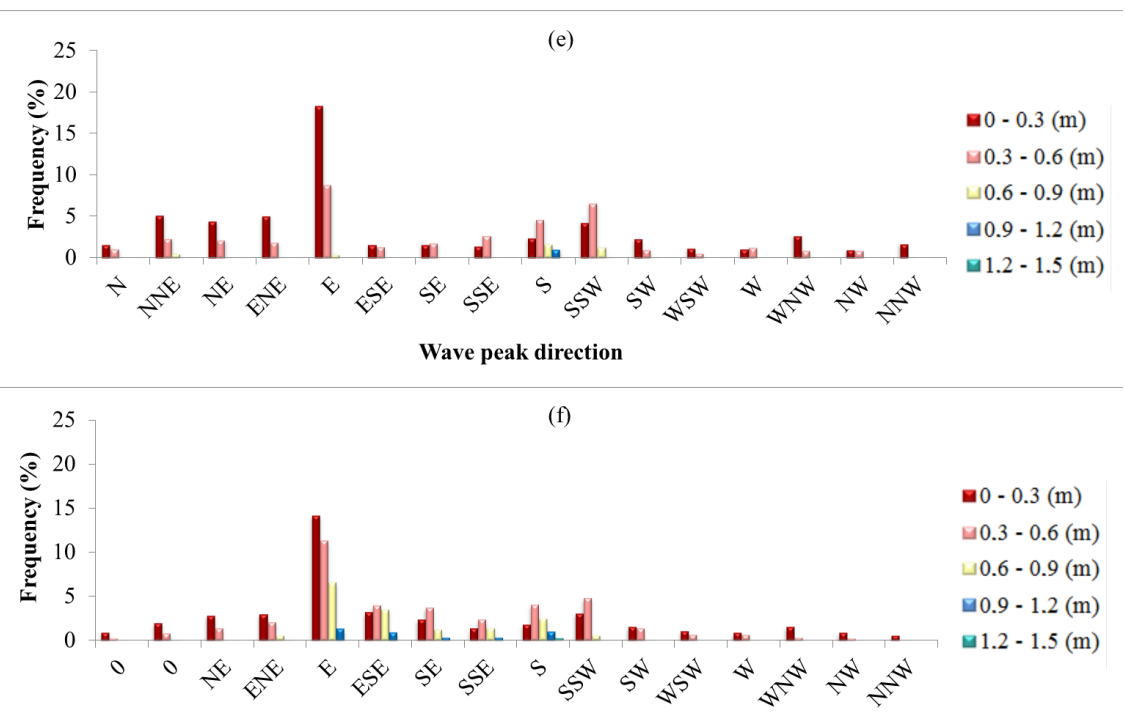

Wave peak direction

Figure 5. Histograms of wave occurrence frequencies for Hs according to peak wave directions. (a) from 01/27/2015 to 02/28/2015; (b) from 03/01/2015 to 03/31/2015; (c) from 04/01/2015 to 04/30/2015; (d) from 05/01/2015 to 05/31/2015; (e) from 06/01/2015 to $06 / 30 / 2015$ and (f) from $01 / 27 / 2015$ to $06 / 30 / 2015$. 
(a)

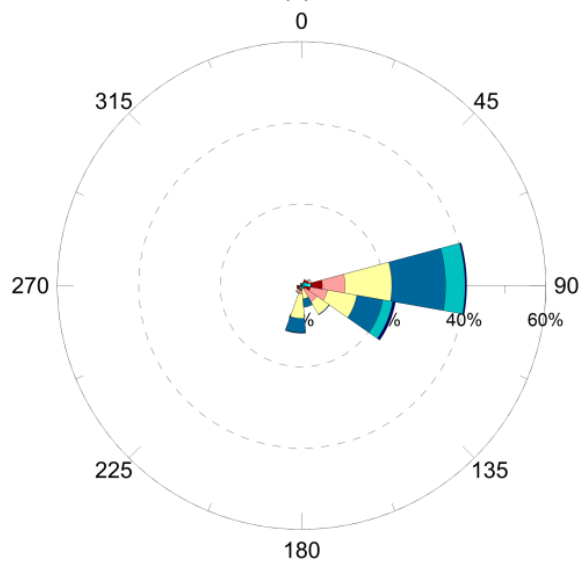

(c)

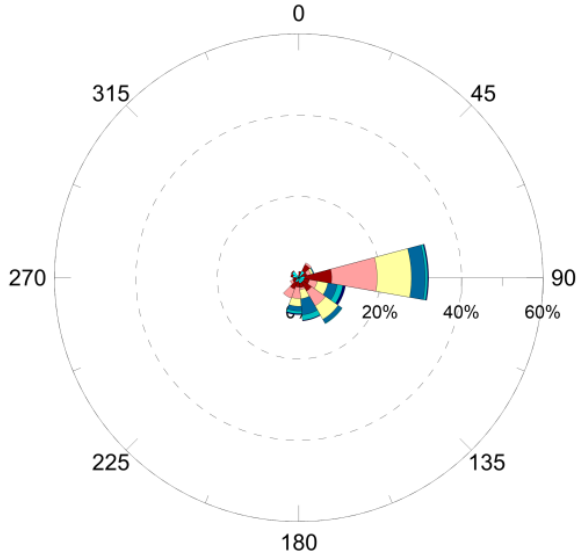

(e)

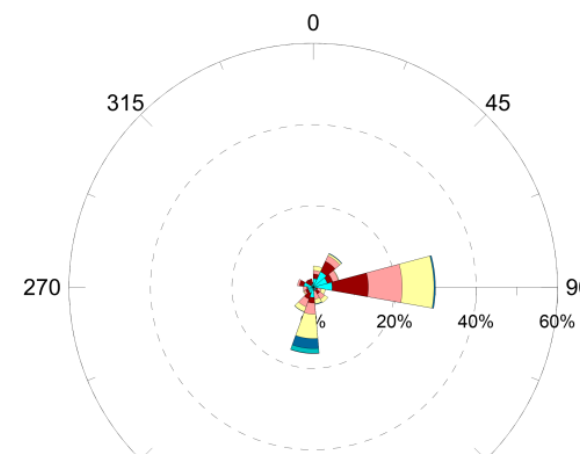

(b)

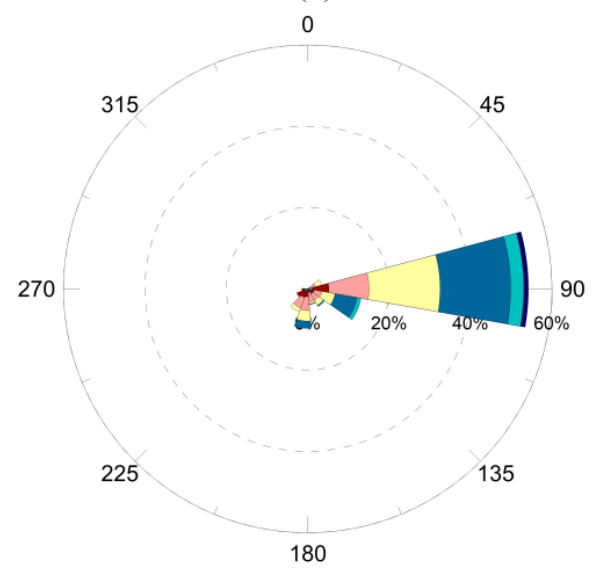

(d)

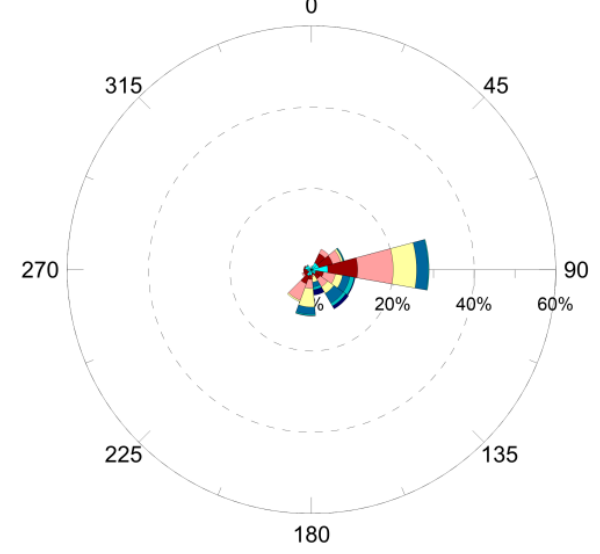

(f)

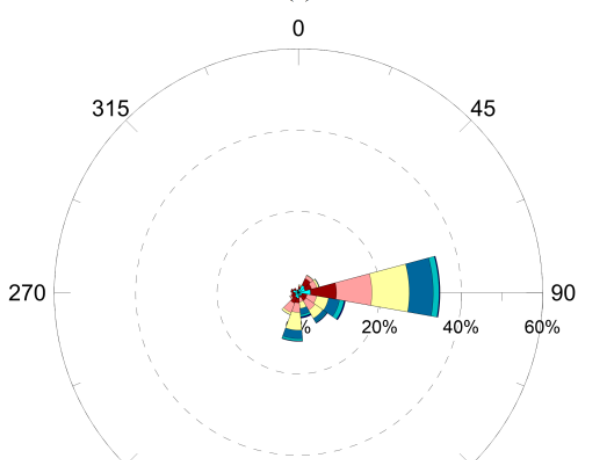

225 135
225

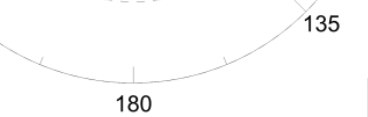

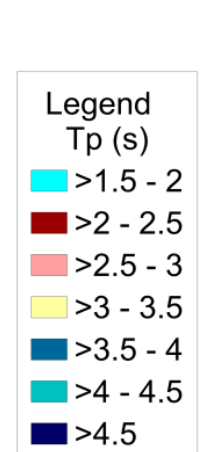

Figure 6. Tp wave rose diagrams according to peak wave directions. (a) from 01/27/2015 to 02/28/2015; (b) from 03/01/2015 to 03/31/2015; (c) from 04/01/2015 to 04/30/2015; (d) from 05/01/2015 to 05/31/2015; (e) from 06/01/2015 to 06/30/2015 and (f) from $01 / 27 / 2015$ to $06 / 30 / 2015$. 


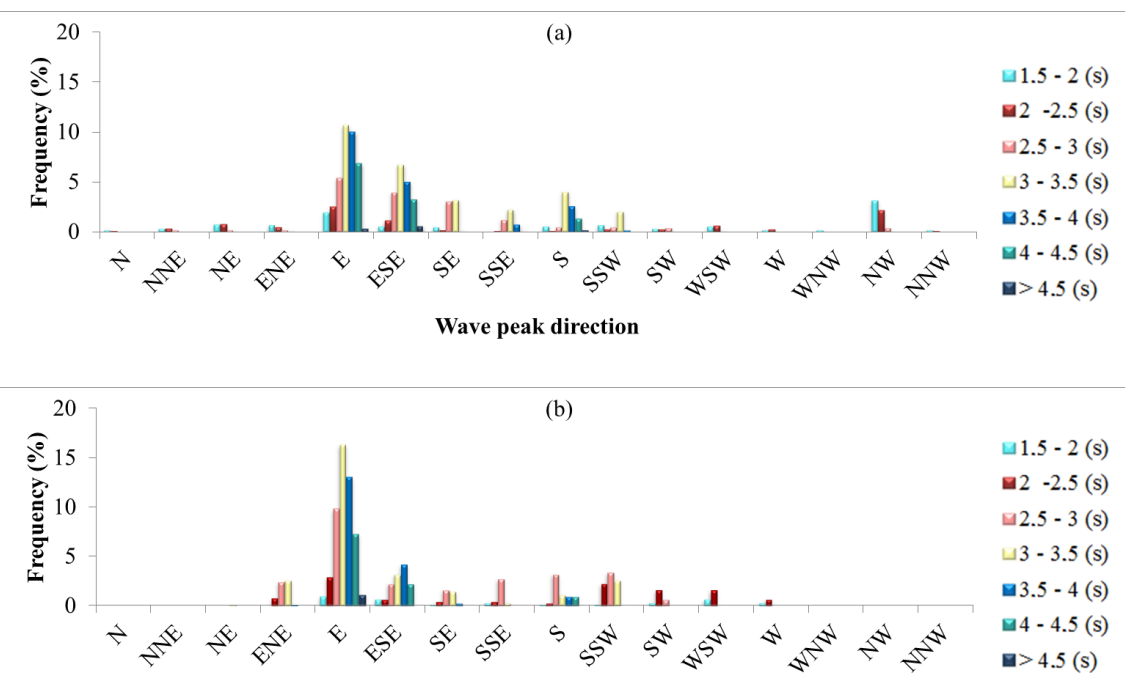

Wave peak direction

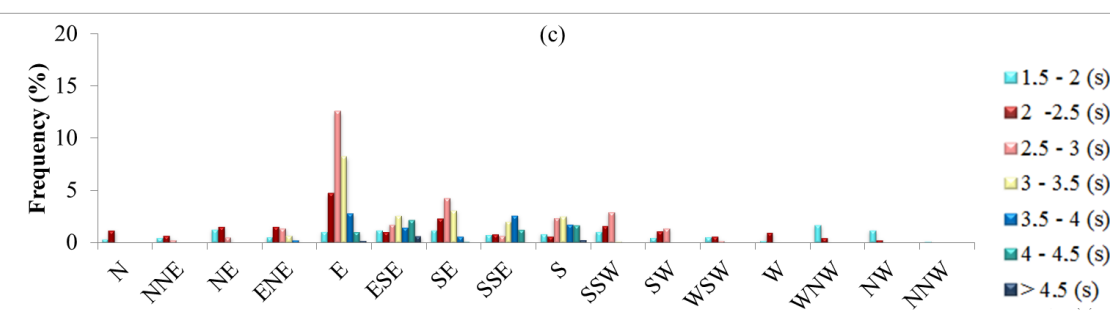

Wave peak direction
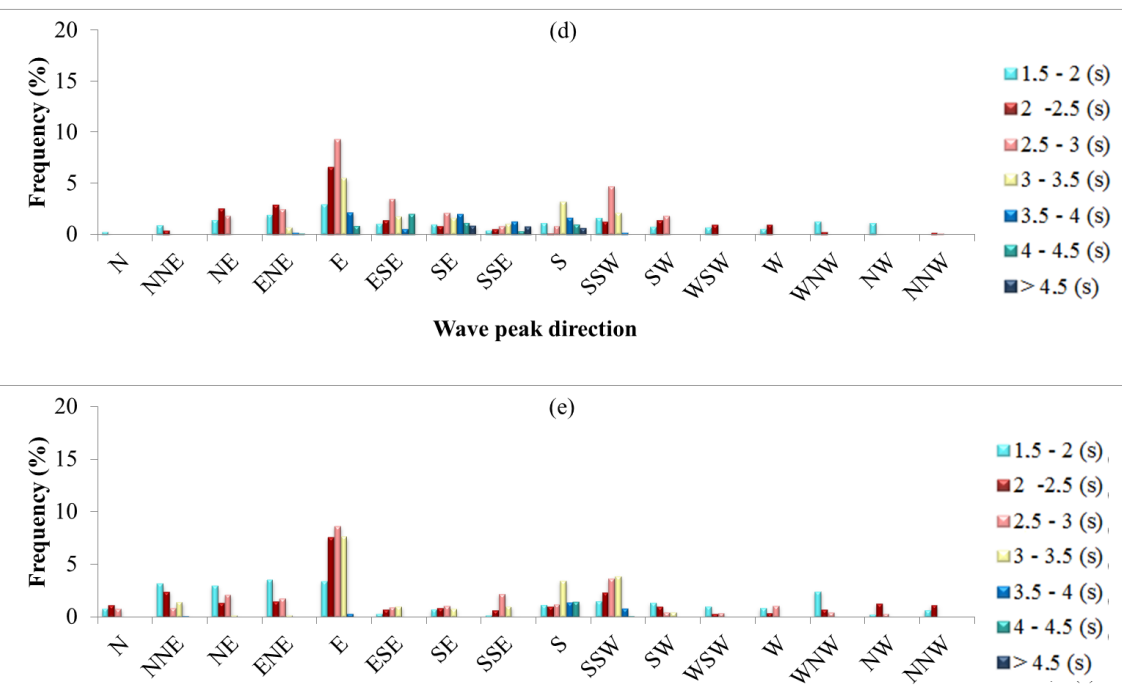

Wave peak direction

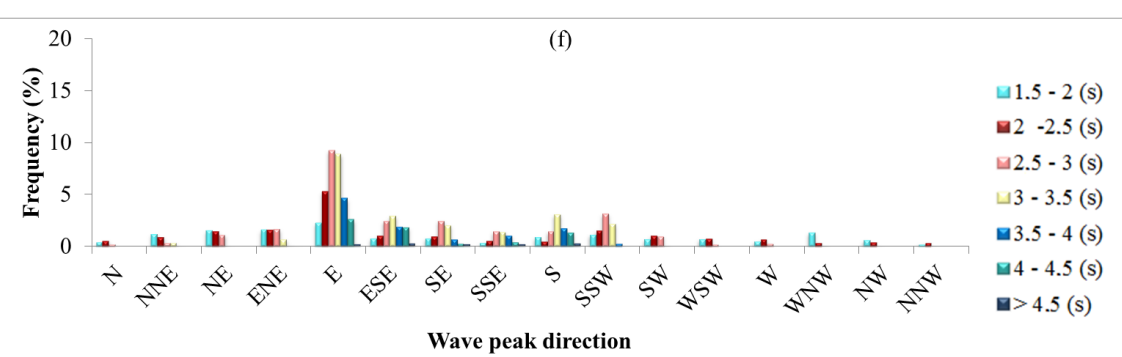

Figure 7. Histograms of wave occurrence frequencies for Tp according to peak wave directions. (a) from 01/27/2015 to 02/28/2015; (b) from 03/01/2015 to 03/31/2015; (c) from 04/01/2015 to 04/30/2015; (d) from 05/01/2015 to 05/31/2015; (e) from 06/01/2015 to $06 / 30 / 2015$ and (f) from $01 / 27 / 2015$ to $06 / 30 / 2015$. 
from $05 / 01 / 2015$ to $05 / 31 / 2015$, from $06 / 01 / 2015$ to $06 / 30 / 2015$, and from $01 / 27 / 2015$ to $06 / 30 / 2015$.

According to Figures from 4 to 7 and the results from the occurrence frequency calculations, it could be verified that waves with east peak direction occurred more frequently throughout the operation period of the waverider buoy in Patos Lagoon (January 27-June 30, 2015), totalizing 33.3\% of the incidences. Following that, the highest frequencies corresponded to waves with ESE (11.5\%), S (9.47\%), SSW (8.48\%), SE (7.66\%), ENE $(5.8 \%)$, SSE $(5.6 \%)$ and NE (4.26\%) peak directions. Regarding the significant wave height, the largest occurrences corresponded to waves with up to 0.3 meters $(41.2 \%)$, from 0.3 to 0.6 meters (38\%), and from 0.6 to 0.9 meters $(16.4 \%)$. Waves with significant heights between 0.9 and 1.2 meters, and between 1.2 and 1.5 meters occurred, respectively, only in $3.97 \%$ and $0.39 \%$ of the waverider buoy records. Waves with peak periods between 2.5 and 3 seconds (25.6\%), 3 and 3.5 seconds (22.1\%) and between 2 and 2.5 seconds $(18.4 \%)$ occurred with higher frequencies. Waves with peak periods between 1.5 and 2 seconds (15.4\%), 3.5 and 4 seconds (10.6\%), and between 4 and 4.5 seconds $(6.68 \%)$ had a lower frequency of incidence. Waves with peak periods greater than 4.5 seconds only occurred in $1.27 \%$ of the cases. In general, it was verified that the highest wave frequencies recorded by the waverider buoy corresponded to short periods (between 2 and 3.5 seconds) and small values of significant wave heights (up to 0.6 meters). The mean Hs, Tp and Dir obtained throughout the mooring period of the waverider buoy in Patos Lagoon are, respectively, 0.35 meters, 2.78 seconds and $102.7^{\circ}$. The short significant wave heights and peak wave periods are attributed to the coastal lagoon's shallow depth (5 meters deep on average) and wind intensities in the region ( $6 \mathrm{~m} \cdot \mathrm{s}^{-1}$ on average during the study period). According to Simão (2016), although the prevailing wind (NE) fetch is wide, the $\mathrm{Hs}$ and $\mathrm{Tp}$ values are attenuated due to the presence of sand spits in Patos Lagoon.

Specifically for the analyzed monthly periods, it was observed that, from January 27 to February 28, 2015, waves with east peak direction presented frequencies of $15.6 \%, 10.8 \%$ and $9.26 \%$, correspondent, respectively, to the significant wave height intervals between 0.6 and 0.9 meters, 0.3 and 0.6 meters and up to 0.3 meters. Waves with ESE peak directions occurred with frequencies of $8.72 \%$ and $8.17 \%$, correspondent to the significant wave height intervals between 0.3 and 0.6 meters and between 0.6 and 0.9 meters, concomitantly. During this period, waves with E peak direction and peak wave periods between 3 and 3.5 seconds (10.7\%), 3.5 and 4 seconds (10.1\%), 4 and 4.5 seconds (6.9\%), and between 2.5 and 3 seconds (5.45\%) were recorded by the waverider buoy with higher frequencies. It was also verified that there was a large incidence of waves with ESE peak periods with values between 3 and 3.5 seconds (6.81\%), 3.5 and 4 seconds (5.09\%), 2.5 and 3 seconds (4\%), and between 4 and 4.5 seconds $(3.36 \%)$.

During March 2015, waves with E peak directions occurred with higher frequencies, totalizing $51.6 \%$ of the records. The largest occurrences were of waves with significant heights between 0.3 and 0.6 meters $(19.9 \%)$, followed by waves with significant heights between 0.6 and 0.9 meters $(17 \%)$ and up to 0.3 meters ( $9.55 \%)$, all of them with $\mathrm{E}$ peak wave direction. Waves with peak periods between 3 and 3.5 seconds and $\mathrm{E}$ peak directions had a higher frequency of incidence (16.3\%), followed by waves with peak periods between 3.5 and 4 seconds (13.1\%), 2.5 and 3 seconds $(9.87 \%)$ and between 4 and 4.5 seconds $(7.28 \%)$, all of them with E peak wave directions.

In April 2015, the largest occurrences were of waves with E peak directions, totalizing $30.82 \%$ of the cases. For this peak wave direction, waves with significant heights of up to 0.3 meters occurred in $14 \%$ of the cases, and with significant heights between 0.3 and 0.6 meters occurred in $12.26 \%$ of them. Waves with peak periods between 2.5 and 3 seconds (12.59\%), 3 and 3.5 seconds $(8.29 \%)$ and between 2 and 2.5 seconds (4.72\%), all of them with $\mathrm{E}$ peak wave directions, had higher frequencies of incidence.

During May 2015, there was still a large incidence of waves with $\mathrm{E}$ peak directions $(27.6 \%)$; however, an increase in the incidence of SSW waves was observed, totalizing $10.17 \%$ of the records. Specifically waves with $\mathrm{E}$ peak directions and significant heights of up to 0.3 meters and between 0.3 and 0.6 meters occurred in $15.33 \%$ and $8.98 \%$ of the cases, respectively. It is important to stress that $5.98 \%$ of the records corresponded to waves with significant heights between 0.3 and 0.6 meters and SSW peak wave directions. Waves with peak periods between 2.5 and 3 seconds, 2 and 2.5 seconds and between 3 and 3.5 seconds had incidences with $\mathrm{E}$ peak wave directions, representing $9.35 \%, 6.66 \%$ and $5.54 \%$ of the cases, respectively. It should be highlighted that $4.79 \%$ of the records made by the waverider buoy corresponded to waves with SSW peak directions and peak periods between 2.5 and 3 seconds.

During the last month, June 2015, waves with E (27.61\%) and SSW (12.4\%) peak directions corresponded to the highest frequencies. Waves with $\mathrm{E}$ peak directions and significant heights of up to 0.3 meters and between 0.3 and 0.6 meters occurred in $18.39 \%$ and $8.80 \%$ of the records, respectively. Waves with SSW peak directions and significant heights of up to 0.3 meters and between 0.3 and 0.6 meters had incidences in $4.33 \%$ and $6.63 \%$ of the cases, respectively. Waves with SSW peak directions and significant heights of up to 0.3 meters and between 0.3 and 0.6 meters had incidences that corresponded to $4.33 \%$ and $6.63 \%$ of the cases, respectively. Waves with E peak directions and peak periods between 2 and 2.5 seconds, 2.5 and 3 seconds and between 3 and 3.5 seconds occurred with frequencies of $7.57 \%, 8.65 \%$ and $7.64 \%$, concomitantly. Waves with SSW peak directions occurred in $2.38 \%, 3.68 \%, 3.89 \%$ of the cases, with peak wave periods between 2 and 2.5 seconds, 2.5 and 3 seconds and between 3 and 3.5 seconds, respectively.

The presented results have much to contribute to the scientific sphere regarding the wave regime characterization in Patos Lagoon since the analyzed wave parameters were acquired through the operation of the first directional waverider buoy moored in the lagoon body. Therefore, it is still not possible to make comparisons with other wave data measured in the coastal lagoon by specific equipment, as they are inexistent until this moment.

However, it is possible to compare the results acquired through the waverider buoy with the ones obtained by Toldo Junior et al. (2006) on wave prediction in Patos Lagoon. In Toldo Junior et al. (2006), the mean values of significant wave heights and wave periods for a spot in the coastal lagoon west margin, very near São Lourenço do Sul, were, respectively, 0.6 meters and 
3.1 seconds in the summer, 0.5 meters and 2.8 seconds in the fall, 0.5 meters and 2.7 seconds in the winter, and 0.6 meters and 3.0 seconds in the spring.

Considering the period that the waverider buoy was in operation in Patos Lagoon, the comparison between the data measured by the equipment and the predictions by Toldo Junior et al. (2006) are made only for the summer and fall.

The mean values of significant wave height, peak period and peak direction acquired through the waverider buoy were, respectively, 0.51 meters, 3.2 seconds and $119^{\circ}$ during the summer, and 0.36 meters, 2.7 seconds and $137^{\circ}$ during the fall. The mean Hs and Tp determined by Toldo Junior et al. (2006) are very close to the ones acquired by the waverider buoy.

The wave directions defined by the referred authors coincide with the wind directions. However, according to Lemke (2015), the linear correlation between the wind directions measured at the Praticagem da Barra do Rio Grande weather station and the peak wave directions obtained by the waverider buoy allowed the author to infer that there is a refraction of waves in Patos Lagoon.

Although the location of the point of comparison between the wave parameters is not exactly the same, the $\mathrm{Hs}$ and $\mathrm{Tp}$ results found by the different methodologies are very similar.

The Hs and Tp values obtained by Nicolodi et al. (2013) in Lake Guaíba (north of Patos Lagoon, at $3 \mathrm{~m}$ deep) using a FSI3D waverider buoy produced by Falmouth Scientific were lower than the correspondent data acquired by the directional waverider buoy in the lagoon body. The referred authors found waves with Hs of up to approximately 0.15 meters and peak wave periods shorter than 3 seconds, from June 16 to August 2, 2015. Those results are consistent with this work since the wind fetch in Lake Guaíba is much smaller than the one in Patos Lagoon main body due to their morphological features. Besides that, the depth from the location where the wave measurements were made in Lake Guaíba (three meters) is much shallower than the one from where the wave measurements were made in Patos Lagoon (six meters).

Low Hs values were also found by Seibt et al. (2013) in Lake Überlingen (Germany) using a wave measurer at a location where the depth is about two meters. Their results showed that waves with $\mathrm{Hs}$ of up to 0.15 meters represented $93 \%$ of the cases. Lake Überlingen has an average depth of 84 meters and it is about $20 \mathrm{~km}$ long and $2.3 \mathrm{~km}$ wide. Although it has an average depth (84 meters) much deeper than Patos Lagoon's (five meters), this lake has a much smaller area, which reduces its wind fetch. Thus, as the equipment's local depth (two meters) and the wind fetch in Lake Überlingen are smaller than the waverider buoy's local depth (six meters) and the wind fetch in Patos Lagoon, the Hs values in Lake Überlingen are reduced as well.

Larger $\mathrm{Hs}$ and $\mathrm{Tp}$ values were found in Moeini and Etemad-Shahidi (2009) to validate a wave-generating model (SWAN - Simulating Waves Nearshore) in Lake Erie (in the Canada-United States boarder) through the statistical comparison between the modeled and measured wave data. This lake is about $100 \mathrm{~km}$ wide and $400 \mathrm{~km}$ long, with an average depth of 19 meters. The wave data were collected by three wave buoys (named '45005', '45132' and '45142') in locations closer to the shore, with depths of, respectively, 14.6, 22 and 27 meters. From the presented results of the mean modeled $\mathrm{Hs}$ and $\mathrm{Tp}$ values and their respective bias (difference between the mean modeled and observed value), it was verified that the mean $\mathrm{Hs}$ and Tp obtained by the three wave buoys (45005, 45132 and 45142) were, respectively, 0.54 meters and 3.76 seconds, 0.90 meters and 5.4 seconds, and 0.93 meters and 6.28 seconds. Lake Erie and Patos Lagoon have a NE-SW general orientation and an average length of $400 \mathrm{~km}$, but they differ in their respective average depths, average widths and lake/coastal lagoon morphological features. Thus, it can be observed that the mean $\mathrm{Hs}$ and $\mathrm{Tp}$ values from the lake are larger than their correspondent values in Patos Lagoon, as the local depths of the moored buoys in Lake Erie are much deeper than the waverider buoy's local depth in Patos Lagoon. The larger Hs and Tp values from Lake Erie can also be attributed to the greater mean wind intensities, which were $7.2,8.1$ and $7.3 \mathrm{~m} . \mathrm{s}-1$, measured at 10 meters higher than the respective buoys (45005, 45132 and 45142). In Patos Lagoon, the mean wind intensity (measured at 10 meters high) was 6 m.s-1 during the mooring period of the waverider buoy.

In the study on the SWAN model validation applied to Lake George (Australia), Smith (2012) statistically compared the model results with data measured by eight wave buoys (waverider type) moored in the lake in 1992. Lake George has an approximate area of $65 \mathrm{~km} 2$ and an average depth of 2.1 meters. Through the Hs time series presented only for October 1992, it was verified that there were waves with Tp of up to 3.5 seconds. Regarding the significant wave height, in general, waves with up to 0.7 meters could be observed. The referred author did not present the mean Hs and Tp values, thus making it difficult to compare with the results obtained in Patos Lagoon.

Wave parameters were modeled for Patos Lagoon in the studies conducted by Simão (2016) and Lemke et al. (2015) using the SWAN model. Simão (2016) performed the wave modeling based on 30 years of wind data (from 1982 to 2012), obtaining Hs and Tp results for a location about six km away from São Lourenço do Sul, where the local depth is three meters. In general, the referred author observed higher frequencies from waves with $\mathrm{Hs}$ of up to 0.4 meters and peak wave periods of up to 2.5 seconds. Although the modeled data analysis location is not exactly the same as the waverider buoy's and the study period (from 1982 to 2012 for the simulation and 2015, first semester, for the measurements with the waverider buoy) is not the same, the results are very close since the mean $\mathrm{Hs}$ and $\mathrm{Tp}$ values recorded by the waverider buoy were 0.35 meters and 2.78 seconds, respectively.

Lemke et al. (2015) verified the calibration of the SWAN model applied to Patos Lagoon during March 2015 through the statistical analysis between the modeled data results (obtained at the same location of the waverider buoy) and the observed data measured by the directional waverider buoy. The modeled ( 0.57 meters, 3.33 seconds and $105.75^{\circ}$, respectively correspondent to Hs, Tp and Dir) and observed results ( 0.50 meters, 2.45 seconds and $75.83^{\circ}$, respectively correspondent to $\mathrm{Hs}$, Tp and Dir) were very close. The authors noted that the model had a tendency of underestimating the observed data.

The lack of research based on the measurement of wave parameters in sheltered environments, such as lakes and coastal lagoons, is a great limitation to the discussions of this work. The comparison between the measured wave results in Patos Lagoon with wave data measured by wave buoys in the Rio 
Grande do Sul coast (studies conducted by STRAUCH et al., 2009, and ASSIS et al., 2013) is not possible since the oceanographic conditions of the open sea are distinct from the characteristics of Patos Lagoon.

Although the discussions from this work are still limited, the results here presented have formed a consistent basis for the wave regime characterization in Patos Lagoon, as well as for several other studies in the areas of wave modeling, sedimentary transport and designing of costal works.

\section{CONCLUSION}

This study allowed the pattern of waves that occur in Patos Lagoon's main body to be characterized during the period from January 27 to June 30, 2015, by using the measurements made by the directional waverider buoy. In addition to that, the identification of classes of higher monthly frequencies of significant wave heights, peak periods and peak directions was also done, as well considering the whole period covered by this study.

In general, the highest frequencies recorded by the waverider buoy corresponded to waves with $\mathrm{E}$ incidence, short periods (between 2.5 and 3.5 seconds) and small values of significant wave heights (up to 0.6 meters). The short significant wave heights and peak periods are explained by the Patos Lagoon's shallow depth. This work is innovative with respect to measurements of wave parameters using a waverider buoy in Patos Lagoon's body. Thus, it will certainly contribute to several other studies that might still be conducted in this region. It is very important to continue the operation of specific equipment, such as the waverider buoy used, to identify the wave pattern for a period of an entire year, thus characterizing the four seasons. It should be highlighted that it would be very interesting to continually maintain more pieces of equipment in different regions of the lagoon in order to later characterize the Patos Lagoon's wave climate.

\section{ACKNOWLEDGEMENTS}

- To the research group from the "Rede Ondas" project for operating the first directional waverider mooring in Patos Lagoon;

- To the research groups from FURG: LEC (Coastal Engineering Laboratory) and LOG (Geological Oceanography Laboratory) for the performed campaigns.

\section{REFERENCES}

ASSIS, L. E.; BELUCO, A.; ALMEIDA, L. E. B. Avaliação e aproveitamento da energia de ondas oceânicas no litoral do Rio Grande do Sul. Revista Brasileira de Recursos Hídricos, v. 18, n. 3, p. 21-29, 2013. http://dx.doi.org/10.21168/rbrh.v18n3.p21-29.

DATAWELL BV. Operating Manual W@ves21 Software for Datawell Waverider Buoys. Holanda, 2006. 23 p.

DATAWELL BV. Datawell Waverider Reference Manual. Holanda, 2010. 134 p.
FISCHER, A.; CALLIARI, L. J. Variações morfodinâmicas das praias do "Saco do Laranjal", costa noroeste do estuário da Lagoa dos Patos, RS. Pesquisas em Geociências, v. 38, n. 3, p. 283-296, 2011. Available from: <http://www.ufrgs.br/igeo/pesquisas/3803/6-3803. pdf>. Access on: 15 apr. 2013.

FONTOURA, J. A. S.; NICOLODI, J. L.; ROMEU, M. A. R.; FILHO, E. M.; LEMKE, N.; AGUIAR, D. F.; GOULART, M. M. Medição direcional de ondas na Lagoa dos Patos, RS, Brasil. In: CONGRESSO HIDROVIÁRIO DA SOCIEDADE BRASILEIRA DE ENGENHARIA NAVAL, 2015, Manaus. Anais... Manaus: SOBENA, 2015. CD-ROM.

LEMKE, N. Morfodinâmica da Embocadura do Arroio Carahá, Lagoa dos Patos, São Lourenço do Sul-RS. 2015. 346 f. Tese (Doutorado em Oceanografia Física, Química e Geológica) - Universidade Federal do Rio Grande, Rio Grande, 2015.

LEMKE, N.; FONTOURA, J. A. S.; CALLIARI, L. J.; AGUIAR, D. F.; MELO, E.; NICOLODI, J. L.; ROMEU, M.; GOULART, M. M. Estudo comparativo entre modelagem e medições de ondas na Lagoa dos Patos - RS, Brasil. In: SIMPÓSIO SOBRE ONDAS, MARÉS, ENGENHARIA OCEÂNICA E OCEANOGRAFIA POR SATÉLITE, 11., 2015, Arraial do Cabo. Anais Eletrônicos... Arraial do Cabo, 2015. Available from: < http://media.wix.com/ ugd/f9878c_29ebe79678074b92bcb495f7beeb39d1.pdf>. Access on: 14 jan. 2015.

MACHADO, M. D. Um estudo sobre o clima de ondas e o transporte de lama ao Largo da Praia do Cassino, RS. 2013. 346 f. Tese (Doutorado em Engenharia Oceânica) - Universidade Federal do Rio de Janeiro, Rio de Janeiro, 2013.

MARTINS, I. R.; VILLWOCK, J. A.; MARTINS, L. R.; BEMVENUTI, C. E. The Lagoa dos Patos Estuarine Ecosystem (RS, BRAZIL). Pesquisas em Geociências, v. 22, p. 5-44, 1989.

MIRANDA, L. B.; CASTRO, B. M.; KJERFVE, B. Princípio de oceanografia física de estuários. São Paulo: Edusp, 2002. 432 p.

MOEINI, M. H.; ETEMAD-SHAHIDI, A. Wave parameter hindcasting in a lake using the SWAN model. Scientia Iranica, v. 16, n. 2, p. 156-164, 2009. Available from: <http://archive. scientiairanica.com/PDF/Articles/00000850/etemad-shahidi. pdf $>$. Access on: 18 dec. 2015.

MÖLLER JUNIOR, O. O.; LORENZZENTTTI, J. A.; STECH, J. L.; MATH, M. M. LORENZZENTTI, J. A.; STECH, J.; MATA, M. M. The Patos Lagoon summertime circulation and dynamics. Continental Shelf Research, v. 16, n. 3, p. 335-351, 1996. http:// dx.doi.org/10.1016/0278-4343(95)00014-R.

MOURA, T. G. R.; FORTES, C. J.; NEVES, C. Aplicação da transformada de Hilbert-Huang para caracterização da dinâmica costeira. Parte 2: grandezas vetoriais. Revista Brasileira de Recursos Hidricos, v. 17, n. 2, p. 157-170, 2012. http://dx.doi.org/10.21168/ rbrh.v17n2.p157-170. 
NEVES, C. F. A importância da caracterização da corrente para a correta determinação do comprimento e da altura das ondas. Parte 3: velocidades e acelerações orbitais. Revista Brasileira de Recursos Hidricos, v. 19, n. 3, p. 239-262, 2014. http:/ /dx.doi.org/10.21168/ rbrh.v19n3.p239-262.

NICOLODI, J. L.; TOLDO JUNIOR, E. E.; FARINA, L. Dynamic and resuspension by waves and sedimentation pattern definition in low energy environments. Guaíba Lake (Brazil). Brazilian Journal of Oceanography, v. 61, n. 1, p. 55-64, 2013. http://dx.doi. org/10.1590/S1679-87592013000100006.

PIMENTA, F. M.; MENDES, D. A. R.; SOUTO, A.; MELO, E.; NETO, F. L. V.; FRANCO, D.; PEREIRA, N. C.; CASTELÃO, G. P.; HAMMES, G.; BARLETTA, R.; ROMEU, M. A. R. Técnicas aplicadas no fundeio e manutenção de um ondógrafo direcional. Revista Brasileira de Recursos Hidricos, v. 18, n. 2, p. 281-296, 2013. http://dx.doi.org/10.21168/rbrh.v18n2.p281-296.

SEIBT, C.; PEETERS, F.; GRAF, M.; SPRENGER, M.; HOFMANN, $\mathrm{H}$. Modeling wind waves and wave exposure of nearshore zones in medium-sized lakes. Limnology and Oceanography, v. 58, n. 1, p. 23-36, 2013. http://dx.doi.org/10.4319/lo.2013.58.1.0023.

SILVA, G. C.; ALFREDINI, P. Aplicação de programa de cálculo de propagação de onda nas praias de Itanhaém, SP. Revista Brasileira de Recursos Hidricos, v. 6, n. 3, p. 13-31, 2001. http://dx.doi. org/10.21168/rbrh.v6n3.p13-31.

SIMÃO, C. E. Estudo do Padrão de Ondulações na Lagoa dos Patos utilizando o Modelo SWAN (DELFT3D), RS, Brasil. 2016. 89 f. Dissertação (Mestrado em Engenharia Oceânica) - Universidade Federal do Rio Grande, Rio Grande, 2016.

SMITH, A. G. Wave induced sediment mobility modelling: bedforms, sediment suspension and sediment transport. 2012. 145 f. Tese (Faculty of Engineering \& Industrial Sciences) - Swinburne University of Technology, Melbourne, 2012.

STRAUCH, J. C.; CUCHIARA, D. C.; TOLDO JUNIOR, E. E.; ALMEIDA, L. E. S. B. O Padrão das Ondas de Verão e Outono no Litoral Sul e Norte do Rio Grande do Sul. Revista Brasileira de Recursos Hídricos, v. 14, n. 4, p. 29-37, 2009. http://dx.doi. org/10.21168/rbrh.v14n4.p29-37.
STRAUCH, J. C.; SCHMIDT, R. M.; ROCHA, F. R. Animação de espectros direcionais de ondas em 3D. Revista Brasileira de Recursos Hidricos, v. 6, n. 4, p. 157-163, 2001. http://dx.doi.org/10.21168/ rbrh.v6n4.p157-163.

TOLDO JUNIOR, E. E. Morfodinâmica da Lagoa dos Patos, Rio Grande do Sul. Pesquisas em Geociências, v. 18, n. 1, p. 58-63, 1991.

TOLDO JUNIOR, E. E. Sedimentação, predição do padrão de ondas, e dinâmica sedimentar da antepraia e zona do surf do sistema lagunar da Lagoa dos Patos, RS. 1994. 183 f. Tese (Doutorado em Geociências) - Universidade Federal do Rio Grande do Sul, Porto Alegre, 1994.

TOLDO JUNIOR, E. E.; ALMEIDA, L. E. S. B.; CORRÊA, I. C. S.; FERREIRA, E. R.; GRUBER, N. L. S. Wave prediction along Lagoa dos Patos Coastline, Southern Brazil. Revista Atlântica, v. 28, n. 2, p. 87-95, 2006. Available from: <https://www.seer.furg. br/atlantica/article/view/790>. Access on: 24 nov. 2014.

WESTHUYSEN, A. J. V. D. Modeling of depth-induced wave breaking under finite depth wave growth conditions. Journal of Geophysical Research, v. 115, p. 1-19, 2010. Available from: < http:// onlinelibrary.wiley.com/doi/10.1029/2009JC005433/epdf>. Access on: 28 july 2016.

\section{Authors contributions}

Natália Lemke: participated in the field (waverider buoy mooring), methodology for the data analysis, data analysis, and in the interpretation of the results.

Lauro Julio Calliari: participated in the field (waverider buoy mooring), methodology for the data analysis, data analysis, and in the interpretation of the results.

José Antônio Scotti Fontoura: participated in the field (waverider buoy mooring), methodology for the data analysis, data analysis, and in the interpretation of the results.

Déborah Fonseca Aguiar: participated in the field (waverider buoy mooring), methodology for the data analysis, data analysis, and in the interpretation of the results. 